\section{Delta Journal of Science}

Available online at

https://djs.journals.ekb.eg/

Research Article

\title{
GEOLOGICAL AND STRATIGRAPHICAL STUDIES ON THE SUBSURFACE SEQUENCE IN GIBB AFIA-2 WELL, NORTHERN WESTERN DESERT, EGYPT
}

Akmal M. Marzouk', Fadia Latif Obeid², Abd El-Aziz A. Mahmoud², Nader Ahmed Edress², and Allam Ahmed Allam $^{3}$

1. Geology Department, Faculty of Science, Tanta University

2. Geology Department, Faculty of Science, Helwan University

3. General Petroleum Company (GPC)

\footnotetext{
Abstract: the purpose of the present study is investigated the subsurface rocks of Gibb Afia-2 well in terms of their stratigraphical, sedimentological, and paleontological characteristics. The following topics are emphasized forming the general outline of this study:

1. Lithostratigraphic analysis of the studied well and matching the stratigraphic succession with the general stratigraphy of the northern Western Desert.

2. Description of structural elements and tectonic features and their relation to the general structural framework of the Western Desert.

3. Characterizing the nature of different facies, especially those associated with oil generation and accumulation.

4. Biostratigraphic analysis and determination of the faunal content of the studied well.

Keywords: Western Desert of Egypt, Gibb Afia, Well description, Lithostratigraphic Units, Biostratigraphic Units, Chronostratigraphic Units, Structures, Oil and gas prospects.
}

\section{Introduction:}

The Western Desert of Egypt comprises the area west of the River Nile and Delta. It covers about $700000 \mathrm{~km}^{2}$, about two-thirds of the area of Egypt. It extends $1000 \mathrm{~km}$ from the Mediterranean Sea to the Sudanese Border in the south and $600 \mathrm{~km}$ to $800 \mathrm{~km}$ from the Nile valley to the Libyan border in the west (Figure 1).

The Western Desert has enormous oil potential and may soon emerge as a major petroleum province. Many promising areas await detailed examination and are virtually untested by drilling. A study concerning the petroleum

Resources of the Western Desert suggested that about $90 \%$ of oil and $80 \%$ of gas reserves remain undiscovered (WEC, 1995).

Recent active oil exploration work in the Western Desert of Egypt has revealed the presence of a subsurface stratigraphic column, which ranges in age from the Paleozoic to the Recent (Figure 2). A north south oriented basin covered wide stretches in the northwestern reaches of the Western Desert and can be considered as a northern extension of Libya's Kufra basin. It is locally known as Ghazalat Basin (Keeley, 1989; 


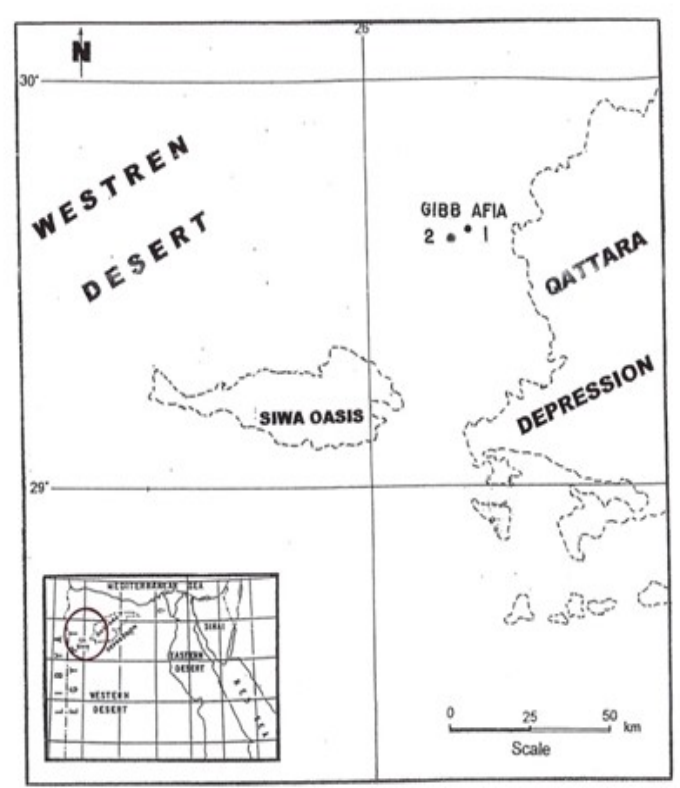

Figure 1: Location map of the studied well, Western Desert, Egypt.

figure 3). The Basin contains thick Paleozoic sequence, ranging in age from Cambrian to Carboniferous. It contains no Lower Mesozoic sediments but has a thick Cenomanian - Eocene fill (WEC 1984, 1995). The Cretaceous and Tertiary rocks seem to be qualified for hydrocarbon generation and oil entrapment. The carbonates, largely or exclusively making most units of the Cretaceous and Tertiary systems, have a dual capacity for hydrocarbon generation and entrapment. The entrapment capacity of these carbonates is favored by their deformation due to the tectonic movements. The importance of carbonates as a source rock for hydrocarbon is increasing in the last 50 years. According to some geochemical studies, giving the proper conditions, carbonate rocks may surpass the traditional shale as source rocks for hydrocarbons (GPC, 1973).

The basic data used in this study are based mainly upon the exploration activities of the General Petroleum Company (GPC) and includes the entire succession of the Gibb Afia-2 well (Lat. 29 ${ }^{\circ} 3^{\prime}$ 32.93' $\mathrm{N}$ and Long. $\left.26^{\circ} 11^{\prime} 47.40^{\prime \prime} \mathrm{E}\right)$. The well is located at the extreme west of the north Western Desert, to the west of the Qattara Depression (Figure 1).

Recent literatures covering the study well and adjacent areas are represented by several authors, such as Abd El Gawad et al. (1996), Abu El-Naga (1984), Amine (1961), Andrawis (1971, 1972), Ayyad and Ismail (1992), Babaev (1968), Babaev et al. (1967), Beckman (1967), Blair (1955), Dahi and Shahin (1992), EGPC (1986, 1992), El-Daker (1974), El-Etr (1977), ElEtr and Mostafa (1980), El-Hashemi (1972), ElKhoriby (1994), El-Malky (1985), El-Sweify (1975), ElZarka and Radwan (1985), Gezeery et al. (1972),
Gondwana and EGPC (1987), GPC (1973), Johnson (1958), Kazatchenko et al. (1970), Khalil (1973, 1997), Mousa (1986), Paleoservices and EGPC (1986), Ragab and Khaled (1989), Marzouk (2004), and Zarif (2006).

\section{WELL HISTORY}

In 1955-1956 Sahara Petroleum Company (Sapetco) delineated the Gibb Afia by seismic, gravity and surface geology as being an anticlinal structure. well is located on the eastern flank of the structure. New GPC seismic results showed the apex of the structure to lie at $13 \mathrm{~km}$ west of Gibb Afia-IX well. The phantom horizon chosen for the map was interpreted to be within the Lower Cretaceous and being 200-250 m higher than Gibb Afia-IX well. The well penetrated a very reduced, highly eroded, section of Upper Cretaceous. It was bottomed in Silurian sands at drill depth 2492 m (Figure 4).

\section{WELL DESCRIPTION}

\section{Tertiary}

\section{Middle Miocene}

\section{(Depth 0-82 m, thickness 62m)}

The Middle Miocene is mainly represented by shallow marine reefal to lagoonal facies. The upper part of the section is composed of reefal limestone, followed by a section of shale. The limestone is tannic white, pinkish white, medium hard to hard, vuggy, pinpoint porosity, and fossiliferous at parts. The intercalated shale is light gray, brick red at parts, sticky, highly calcareous. 


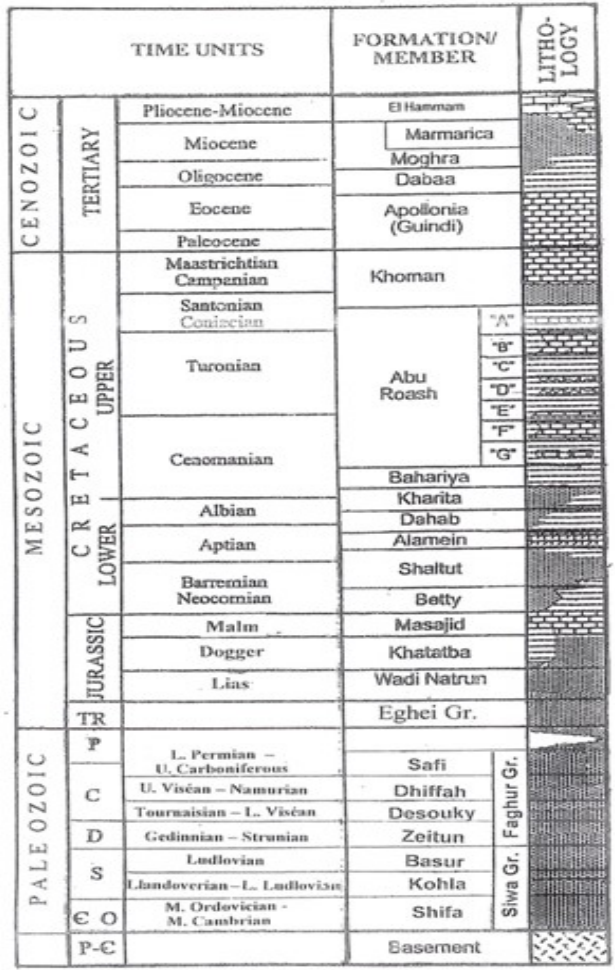

F F⿱艹

igure 2: General stratigraphic column, Western Desert, Egypt

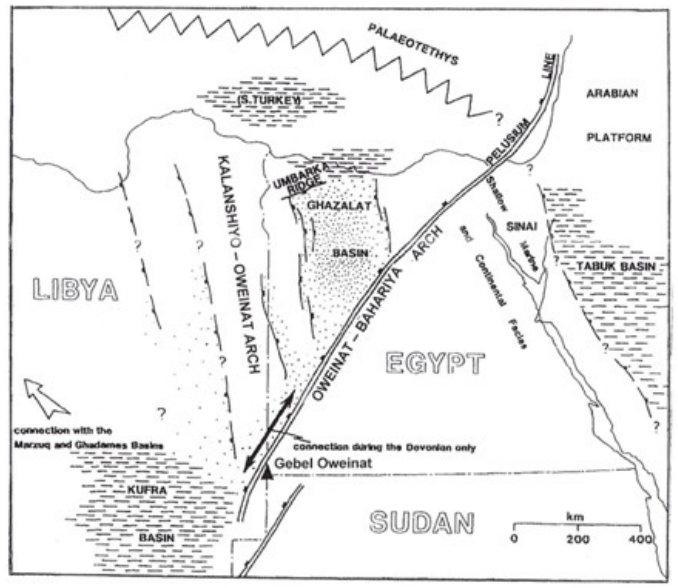
Figure 3: Paleogeography of the Ghazalat Basin, North Western Desert,
Egypt. (After Keeley, 1989)

\section{Lower Miocene}

(Depth 82-148 m, 66 m)

The Lower Miocene section is mainly composed of limestone with some streaks of shale. The limestone is pinkish white, hard to very hard, partly crystalline, argillaceous at drill depths 82-93.5 m, 109-114 $\mathrm{m}$ and
$125-135 \mathrm{~m}$. The intercalated shale is buff, tannic gray, soft to medium hard, and slightly calcareous.

\section{Middle Eocene}

(Depth 148-423m, thickness 275m)

The Middle Eocene section is represented only by 24 $m$ of dolomitic limestone. It is barren of fossils. The loss of circulation from drill depth 174 to $427 \mathrm{~m}$ did not permit the recognition the section from Eocene to Cenomanian. The limestone is medium hard, porous to fairly porous, dolomitic at top, slightly argillaceous at drill depth 230-242 $\mathrm{m}$, intercalated with slightly calcareous shale at drill depth $270-290 \mathrm{~m}$. Cretaceous

\section{Cenomanian}

(Depth 423-782m, thickness 359m)

The Cenomanian section is composed of relatively thick sand deposits of shallow marine conditions. The lower part of the Cenomanian is underlain by a thick barren clastic interval. The sands is colorless, pink, medium to very fine grained, fairly sorted, consolidated to sandstone, which is white, light grayish white, fine grained, medium hard to hard, poorly porous, and partly kaolinitic.

\section{Albian}

(Depth 782-952m, thickness 170m)

The Albian sand is colorless, rose, white, fine to coarse grained, fairly sorted, rarely consolidated to sandstone, which is white, medium hard to hard, poorly porous, partly kaolinitic, and barren of fossils.

Aptian

(Depth 952-1295m, thicknes343m)

The top of the Aptian section is taken on lithological basis. This boundary is tentative due to lack of fauna. The section is mainly composed of shale intercalated with sandstone and siltstone. The sandstone is tan to white, medium hard to hard, fine grained and poorly porous. The siltstone is light gray, medium hard to hard, poorly friable, and porous.

Paleozoic

In Gibb Afia-2 well, the Paleozoic deposits unconformably underlie the Lower Cretaceous with a considerable stratigraphic gap eliminating the uppermost Paleozoic and lowermost Mesozoic.

\section{Upper Devonian}

(Depth 1295-1766 m, thickness $471 \mathrm{~m}$ )

The Upper Devonian section is composed of sand and sandstone. The sand is colorless, white, fine to medium grained, rarely coarse grained, fairly sorted, consolidated to sandstone, which is white, tannic white, medium grained, medium hard to friable, fairly porous, and kaolinitic. The intercalated shale is light gray, partly dark gray, soft, sticky, and poorly blocky. The dolomite is light greenish to purplish white, hard 
to very hard, crystalline, compact and tight, and partly glauconitic.

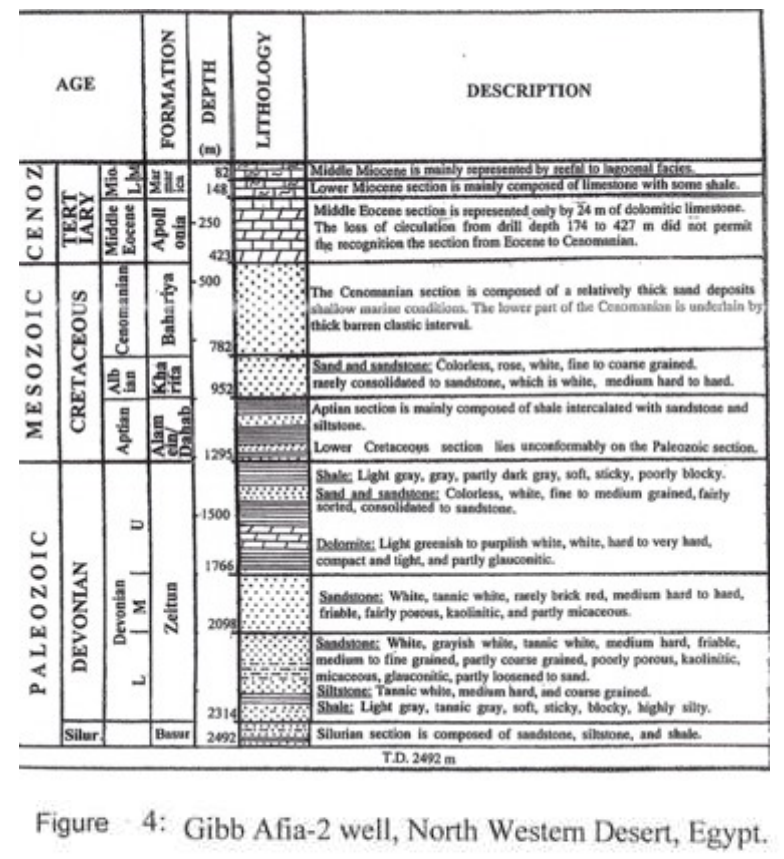

Middle Devonian

(Depth 1766-2098 m, thickness $332 \mathrm{~m}$ )

The Middle Devonian section is composed of sandstone: tannic white, rarely brick red, medium hard to hard, partly friable, porous, kaolinitic, and partly micaceous.

Lower Devonian

(Depth 2098-2312 m, thickness $214 \mathrm{~m}$ )

It is composed of sandstone, siltstone, and shale. The sandstone is grayish white to tannic white, medium hard, partly friable, medium to fine grained, partly coarse grained, poorly porous, partly kaolinitic, micaceous, glauconitic, partly loosened to sand. The siltstone is tannic white, medium hard, and coarse grained. The shale is light gray, soft, sticky, blocky, silty, and grading to argillaceous siltstone.

Silurian

(Depth 2312-2492 m, thickness $178 \mathrm{~m}$ )

The Silurian section is composed of sandstone, siltstone, shale, and barren of fossils.

The sandstone is brown to light gray, fine to medium grained, medium hard, fairly porous, tight, rarely glauconitic, and slightly calcareous. The siltstone is gray, medium hard, fairly porous, tight, micaceous, and argillaceous. The shale is gray, medium hard, fairly porous, tight, partly micaceous, and highly argillaceous.

FAUNAL CONTENT
The following foraminifers are recognized in the Gibb Afia-2 well:

Middle Miocene: Borelis melo, Discorbis obtusus, Elphidium crispum, E. macellum, Guttulina communis, Nonion gransoum, Schlumbergerina sp. Streblus beccarii, Quinquloculina pulchella, and Quinquloculina seminula.

Lower Miocene: Elphidium crispum, Operculina complanata, Operculina sp. Streblus andouini, and Textularia sp.

Cenomanian: Flabellammina sp. Oribitolina sp., Thomasinella fragmentaria, and $T$. punica.

Aptian: Ammobaculites sp., Ammomarginulina sp., Flabellammina sp., and Tritaxia pyramidata.

Devonian: Hyperammina sp., Oxinoxis ligula, Protennina cumberlandiae, Psammosphaera gracilis, Thurammina deformens, $T$. elliptica, T. tabulate, Thuramminoides sphaeroidalis, and Tolypammina bulbosa.

\section{BIOSTRATIGRAPHIC UNITS}

The recognized foraminifers proved useful results in establishing the following Biozonation. The scheme of Andrawis (1990) is generally followed.

Depth

Biozone

Age

0-82 m

Borelis melo Zone

Middle Miocene

82-148 m

Early Miocene

148-423 m

Middle Eocene

423-782 m

Cenomanian

Thomasinella fragmentaria Zone

782-952 m

Barren of fossils

Albian

952-1295 m Ammobaculites \&

Ammomaginulina spp. Assemblage

Aptian

1295-2314 m Proteonina spp. \&

Assemblage

Thuramminoides

sphaeroidalis

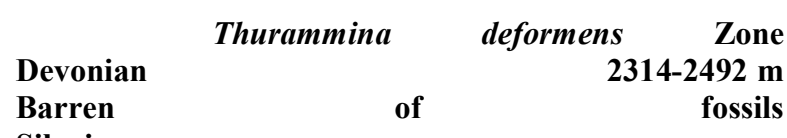

Silurian

\section{LITHOSTRATIGRAPHIC UNITS}

The following lithostratigraphic units are recorded in Gibb Afia-2 well: 


\begin{tabular}{|c|c|c|}
\hline $\begin{array}{l}\text { Depth } \\
\text { Age }\end{array}$ & & Formation \\
\hline $\begin{array}{l}\text { 0-82 m } \\
\text { Middle Miocene }\end{array}$ & Marmarica & Formation \\
\hline $\begin{array}{l}82-148 \mathrm{~m} \\
\text { Lower Miocene }\end{array}$ & Mamura & Formation \\
\hline $\begin{array}{l}\text { 148-423 m } \\
\text { Middle Eocene }\end{array}$ & Apollonia & Formation \\
\hline $\begin{array}{l}423-782 \mathrm{~m} \\
\text { Cenomanian }\end{array}$ & Bahariya & Formation \\
\hline $\begin{array}{l}\text { 782-952 m } \\
\text { Albian }\end{array}$ & Kharita & Formation \\
\hline $\begin{array}{l}\text { 952-1295 m } \\
\text { Aptian }\end{array}$ & Alamein/Dahab & Formation \\
\hline $\begin{array}{l}\text { 1295-2314 m } \\
\text { Devonian }\end{array}$ & Zeitun & Formation \\
\hline $\begin{array}{l}\text { 2314-2492 m } \\
\text { Silurian }\end{array}$ & Basur & Formation \\
\hline
\end{tabular}

\section{CHRONOSTRATIGRAPHIC UNITS}

The dating of the stratigraphic succession of the Gibb Afia-2 well was established based on the aboveidentified biostratigraphic units:

Middle Miocene: The Miocene is mainly represented by shallow marine reefal to lagoonal facies. The upper part of the section is composed of reefal limestone, followed by a section of shale. It comprises the Borelis melo Zone (Zone 78, Andrawis 1990), which is of Serravallian age.

Lower Miocene: The Lower Miocene section is mainly composed of limestone with some streaks of shale. The Lower Miocene section contains the Miogypsina intermedia Zone (Miogypsina complanata-Operculina complanata Zone, GPC 1974; Zone 69, Andrawis 1990) of Burdigalian age.

Middle Eocene: The Middle Eocene section is represented only by $\mathbf{2 4} \mathrm{m}$ of dolomitic limestone. It is barren of fossils.

Cenomanian: The Cenomanian section is composed of relatively thick sand deposits of shallow marine conditions. The upper boundary of the Cenomanian is taken at the first appearance of the foraminiferal Thomasinella fragmentaria Zone (Zone 18, Andrawis 1990).

Albian: The Albian sand and sandstone are barren of fossils.

Aptian: The top of the Aptian section is taken on lithological basis. This boundary is tentative due to lack of fauna. The Aptian section is mainly composed of shale intercalated with sandstone and siltstone, and marked by the presence of Ammobaculites \& Ammomaginulina spp. Assemblage, which is of Aptian age.
Devonian: The Devonian section is composed mainly of shale and sandstone. It contains the foraminiferal assemblage Proteonina spp. \& Thuramminoides sphaeroidalis, as well as the Thurammina deformens Zone (Zone 1, Andrawis 1990), indicate a Devonian age.

Silurian: The Silurian section is composed of sandstone, siltstone, and shale that are barren of fossils.

\section{STRUCTURES}

The Gibb Afia structure lies on the western flank of the large submeridional Qattara Depression. It is a northeast - southwest trending anticline. The northwestern flank of this anticline is longitudinally crossed by a fault down throwing to the northwest. This structure is regarded as an extension of Siwa Alamein swell, which includes Alamein, Qattara, Ghazalat, Gibb Afia, and Siwa uplifts. According to regional seismic surveys, their trends are mostly in the NE - SW direction.

The Gibb Afia structure proved to be complicated by faults that separated it to different blocks (Figures 5 and 6). The structure measures $30 \times 17 \mathrm{~km}^{2}$, with amplitude of more than $220 \mathrm{~m}$. The northeastern part of the fold is complicated by a relatively elevated flexure with small amplitude that having the dimensions $5,5 \times 3 \mathrm{~km}^{2}$ in the northeastern trend. This flexure is separated from the basic structure by a saddle.

Both Gibb Afia 1 \& 2 wells are located almost around the axis of the anticline. The drilling shows that Gibb Afia-1 well, $13 \mathrm{~km}$ apart to the northwest, is in a slightly lower position. The tops of the Upper Cretaceous, Lower Cretaceous, and Paleozoic in Gibb Afia-2 well are about $90 \mathrm{~m}$ higher than these in Gibb Afia-1 well. However, the level difference is more accentuated with depth rating to about $500 \mathrm{~m}$ on the tops of Silurian and Cambro-Ordovician.

The sedimentation from Cambrian to Carboniferous time in the study area is mostly of marine origin. In the Early Paleozoic, the depositional basin was divided into two local depressions (south and north). The south depression included such areas: Siwa, Gibb Afia, Faghur, and Ghazalat. In the Late Paleozoic, these depressions united into a large basin with some separate small local uplifts.

\section{OIL AND GAS PROSPECTS}

The bitumen investigation revealed the irregularity distribution of both chloroform and alcoholic-benzol bitumen types, humic acids, and organic carbon content along the section.

At the top of the section, bitumen content is low, while at drill depth $430 \mathrm{~m}$ and deeper this content is relatively higher. The chloroform bitumen content 
ranges from 0,0006 to $0,16 \%$, which average of $0,01 \%$. The alcoholic-benzol type content fluctuates nearly within the same range i.e. the $p$ factor is nearly equals to one. From the frequency distribution curve of rock bitumenosity traces of bitumen migration movement had been detected

Capillary extracts declared that both oil pitch and pitch bitumen are the predominant types in Cenomanian, Albian, Aptian, and Devonian deposits

indicating moderate degree of metamorphism. Other type of lower metamorphosed degree as oil and light bitumen types are recorded at some intervals, while the higher metamorphosed type (pitch asphaltene) is recorded in a streak of top Albian only.

The humic acids content is low, it ranges from 0,00008 to $0,0032 \%$ only. Organic carbon content has average of $0,6 \%$.

Therefore, in spite of the presence of moderately metamorphosed bitumen, yet the maturity seems to be unfavorable enough for oil generation. This may be attributed to low content of organic carbon and lack of enough thickness of shaly beds.

\section{CONCLUSIONS}

The following are the important conclusions obtained from the drilling data:

1. The Gibb Afia-2 well is spudded in the Miocene rocks and continued to $174 \mathrm{~m}$. Then circulation was lost till $427 \mathrm{~m}$. The interval 148-174 $\mathrm{m}$ is barren limestone and is considered as Eocene age based on lithology. At $174 \mathrm{~m}$ Cenomanian rocks were encountered and followed by Lower Cretaceous rocks at $720 \mathrm{~m}$, which lie unconformably on a Paleozoic section at $1281 \mathrm{~m}$ and drilling was ended at $2492 \mathrm{~m}$ in the Lower Paleozoic.

2. Due to the scarcity of the fauna in the samples of this well some stratigraphic tops of the section were taken on lithological basis and electric logging correlations, e.g. the boundary between Cenomanian and Lower Cretaceous.

3.TheGibbAfia-2 well did not reach the basement but by the interpretation of geophysical data and correlation with the neighboring wells the top of basement could be estimated at ca. $2950 \mathrm{~m}$.

4. Three stratigraphic gaps were detected. The first gap is represented by the absence of Permian, Triassic, Jurassic, and Carboniferous. The second gap is the absence of the upper most part of Mesozoic sediments i.e. Senonian and Turonian. While the third gap is the absence of Oligocene and Upper Eocene.

5. From the surface to top Cenomanian the section is mainly limestone intercalated by few streaks of shale, while from top Cenomanian until totaldepthis mainly sandstone with shale intercalations.

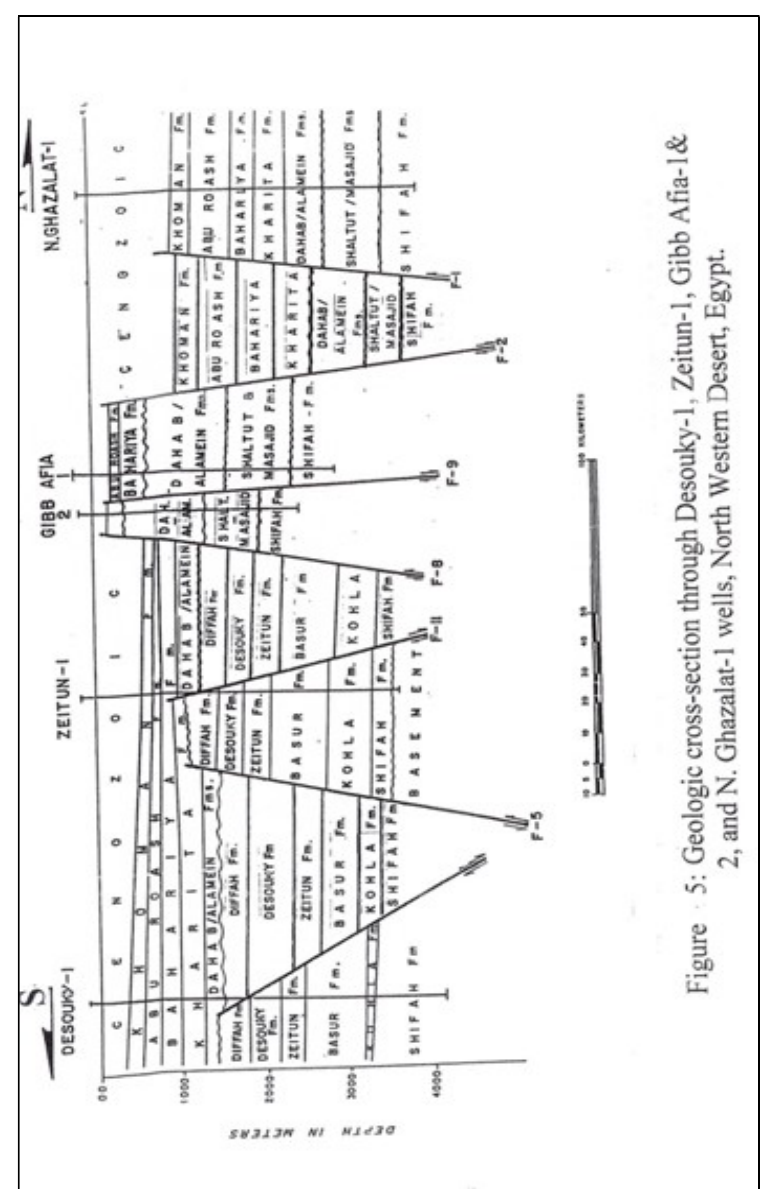

6. All the porous intervals penetrated by the well were found water bearing.

7. No oil or gas shows has been found in the Gibb Afia2 well.

\section{ACKNOWLEDGEMENT}

The present paper is extracted from the M.Sc. Thesis of Allam Ahmed Allam (GPC), which was supervised by Prof. A. Marzouk (Tanta University), Ass. Prof. F. Obeid, Dr. N. Edress, and Dr. A. Mahmoud (Helwan University).

Great appreciation and gratitude are due to the management of the General Petroleum Company (GPC) for giving approval and necessary data to prepare the M.Sc. Thesis. Special thanks are due to Dr. Nadia Zarif (Stratigraphy Department, GPC) for her sincere help. They are also greatly grateful to Prof. Dr. Ahmed Allam (Helwan University), for his valuable suggestions and advice. 


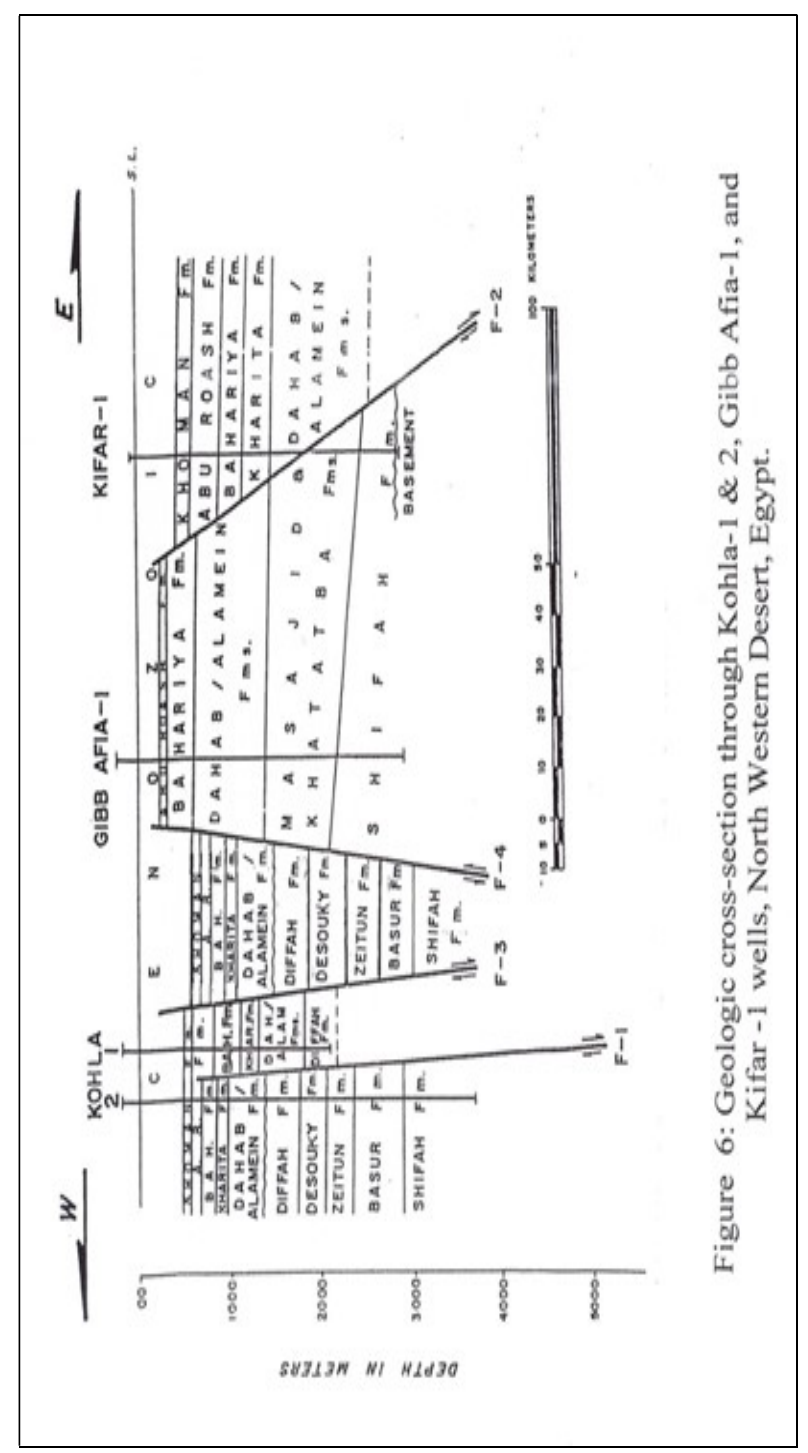

\section{REFERENCES}

Abd El Gawad, E.A., Philip, R.P. \& Zein El Din, M.Y. (1996): Evaluation of possible source rocks in Faghur-Siwa Basin, Western Desert, Egypt.- $13^{\text {th }}$ Petrol Conf., EGPC, Oct. 1996, Cairo, 417-420.

Abu El-Naga, M. (1984): Paleozoic and Mesozoic depocenters and hydrocarbon generating areas, Northern Western Desert of Egypt.- $7^{\text {th }}$ EGPC Petrol. Expl. Prod. Conf., Cairo 23 p.

Amine, M.S. (1961): Subsurface features and oil prospects of the Western Desert, Egypt.- $3^{\text {rd }}$ Arab Petrol. Conf. Alexandria, Paper 16 (B-3), 8 p.

Andrawis, S.F. (1971): Biostratigraphic report on the Gibb Afia well-1, Western Desert, Egypt.- GPC Internal Report, ER 982, 8 p.

Andrawis, S.F. (1972): New biostratigraphic contribution for the upper part of the Paleozoic rocks of Gibb Afia well-1, Western Desert, Egypt.- $8^{\text {th }}$ Arab Petrol. Cong., Algiers, Paper 76 (B-2).
Andrawis, S.F. (1990): Tables of foraminiferal biozones, in Said, R. (Ed.): The Geology of Egypt.- Balkema, Rotterdam/Brookfield, p. 639-648.

Ayyad, A.A. and Ismail, H.E. (1992): Stratigraphy and structure of the Mesozoic in the northern part of the Western Desert, Egypt.- GPC Internal Report, ER 2483, 26 p.

Babaev, A.G. (1968): Geology of the U.A.R..- GPC Internal Report, vol. 1, part $1 \& 2$.

Babaev, A.G.; Nosikov, V.P. and Tadros, S. (1970): Program for aeromagnetic seismic and drilling operations in Siwa and Bahrein areas, Western Desert, Egypt.- Technoexport and GPC, GPC Internal Report, ER 846, 73 p.

Beckman, J.B. (1967): Mesozoic and Paleozoic Stratigraphy of the Western Desert, Egypt.- GPC Internal Report, ER 40.

Blair, R.W. (1955): Final Geological Report Siwa Area, Western Desert, Egypt.- Sahara Petroleum Company (Sapetco), Internal Report, P.C. No. 10.

Dahi, M. and Shahin, A.N. (1992): Paleozoic rocks distribution and hydrocarbon potential in the Western Desert, Egypt.- 11 ${ }^{\text {th }}$ EGPC Expl. Prod. Conf., Cairo, vol. 2, p. 56-78.

Egyptian General Petroleum Corporation (EGPC) (1986): Activity of Oil Exploration in Egypt; 1886-1986.- EGPC, Cairo, 175 p.

Egyptian General Petroleum Corporation (EGPC) (1992): Western Desert, oil and gas fields; a comprehensive overview.- EGPC, Cairo, 431 p.

El-Daker, A. E. (1974): Final Geological Report on Gibb Afia-2 well Western Desert, Egypt.- GPC Internal Report, ER 1262, 4 p.

El-Etr, H.A. (1977): Regional and Economical Geology of Siwa District.- Proc. Symp. Siwa Oasis Res., No. 4, p. 1-32.

EI-Etr. H.A. and Mostafa, A.R. (1980): Structural Setting of Siwa Region.- Geol. Geomorph. Stud. Egypt. Desert, Ain Shams Univ., p. 48-49.

El-Hashimi, M.M. (1972): Sedimentation and oil possibilities of the Paleozoic sediments at Siwa Basin, Western Desert, Egypt.- $8^{\text {th }}$ Arab Petrol. Cong., Algiers, 72, B-3), 12 p.

El-Khoriby, E.M. (1994): Sedimentology of Marmarica Formation (Middle Miocene) in Siwa Area, Northwest of Western Desert, Egypt.- Ph.D. Thesis, Moscow State Univ., Russia, 184 p.

El-Malky, M.G. (1985): Structural Analysis of the Northern Western Desert of Egypt.- Ph.D. Thesis, Imperial College, London, $450 \mathrm{p}$.

El-Sweify, A. (1975): Subsurface Paleozoic Stratigraphy of Siwa - Faghur Area, Western Desert, Egypt.- 9 $^{\text {th }}$ Arab Petrol. Cong., Dubai.

El-Zarka, M.H. and Radwan, I.A. (1985): Tectonic history of the northeastern sector of the Western Desert during the Mesozoic Era, Egypt.- N. Jb. Geol. Paläont. Mh., p. 257-276.

Gezeery, N.H., Mohsen, S.M. and Farid, M.I. (1972): Sedimentary basins of Egypt and their petroleum prospects.$8^{\text {th }}$ Arab Petrol. Cong., Algiers, 83 (B-3).

Gondwana and EGPC (1987): Exploration Evaluation and Prospects, Faghur-Siwa Area, Western Desert, Egypt.EGPC, Cairo. 
General Petroleum Company (GPC) (1973): Evaluation of Exploration Activities and Oil Prospects in Siwa and Adjacent Areas.- GPC, General Exploration Department, Vol. I-V.

Johnson, S.C. (1958): Final geological report on exploratory well Gibb Afia-1.- Sahara Petrol. Comp., Internal Report No. 28.

Kazatchenko, A.; Khalil, N.A. and Gavrilouk, A. (1970): Geological Technical Project of Prospecting Works in Gibb Afia, Western Desert, Egypt.- GPC Internal Report, ER 908, 15p.

Khalil, N.A. (1973): Evaluation of the subsurface drilling results of GPC in Siwa area, Western Desert, Egypt.- GPC Internal Report, ER 1150, 24 p.

Khalil, N.A. (1997): Contribution to the subsurface geology of Siwa area, Western Desert, Ph.D. Thesis, Mansoura Univ., $122 \mathrm{p}$.

Marzouk, A.M. (2004): Biostratigraphical and ecological significance of calcareous nannofossil assemblages from the Paleogene of subsurface sections in the Abu Gharadig Field, Western Desert, Egypt.- N. Jb. Geol. Paläont. Mh., 2004:940, Stuttgart.
Mousa, s. (1986): Evolution of sedimentary basins in the Western Desert of Egypt.- ${ }^{\text {th }}$ Petrol. Expl. Prod. Conf., Cairo, 14 p.

Paleoservices and EGPC (1986): The hydrocarbon potential of the Paleozoic rocks of the Western Desert, Egypt.- GPC, part 1 \& 2, ER 2255.

Ragab, M.A.; Khaled, K.A. (1989): Petrophysical studies on some lithostratigraphic horizons in Siwa Basin, Western Desert, Egypt.- Earth Sc. Ser., Mid. East Res. Cent., Ain Shams Univ., Vol. 3, p. 158-167.

Well Evaluation Conference (WEC) (1984): Geology of Egypt.- WEC Egypt, Schlumberger Middle East S.A., p. 164.

Well Evaluation Conference (WEC) (1995): Western Desert.WEC Egypt, EGPC \& Schlumberger Middle East S.A., p. 60-77.

Zarif, N.A.M. (2006): Paleontological and stratigraphical studies on the subsurface Cretaceous-Tertiary Sequences in Siwa Oasis and surrounding areas, Western Desert, Egypt.Ph.D. Thesis, Fac. Sc., Tanta Univ., 217 p.

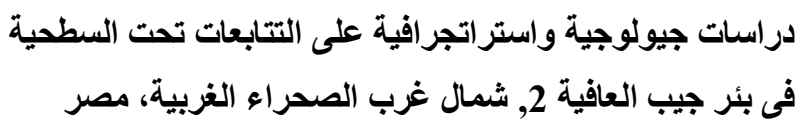

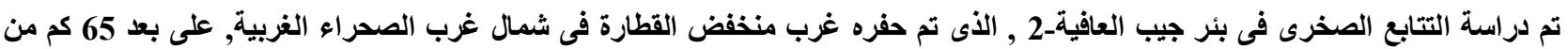

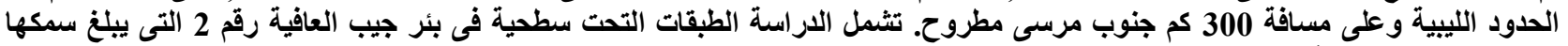
2492 مترا, ويحتوى فيها التتابع الصخرى على رسوبيات من عصور الثالث, الطباشيرى, الايفونى, والسيلورى فئر.

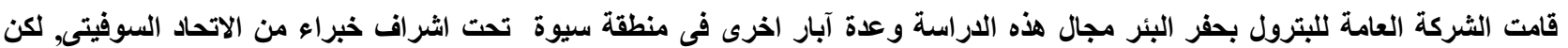

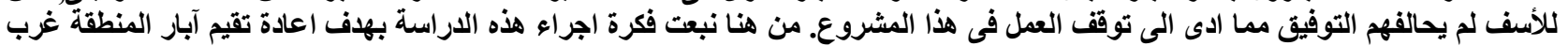

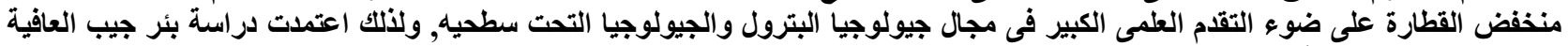
رقم 2 على عدة محاور أهمها:

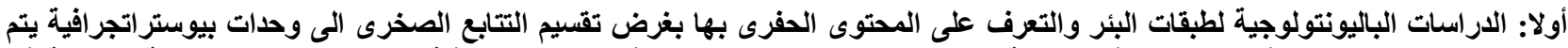

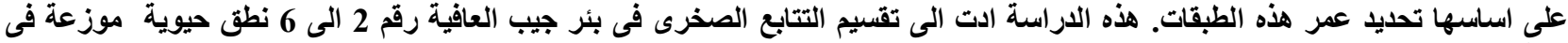
القطاع المدروس على الوجه التلى الطئ:

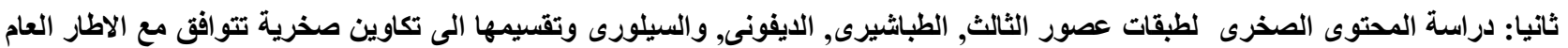

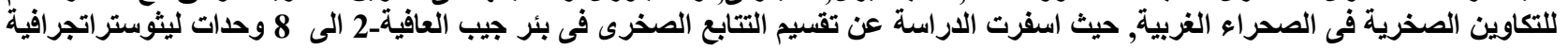

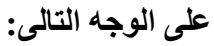

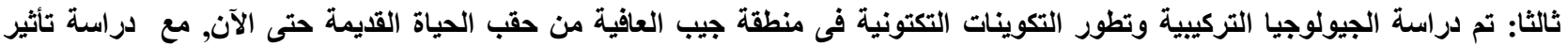

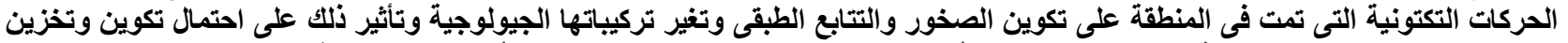

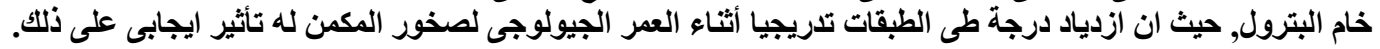

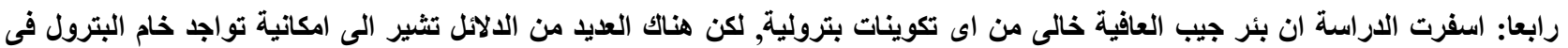

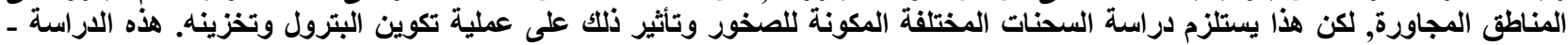

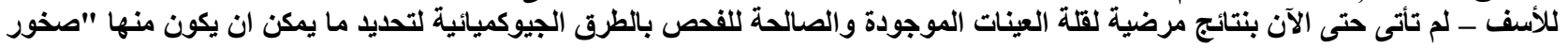




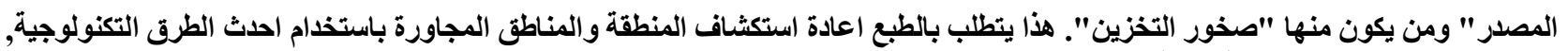

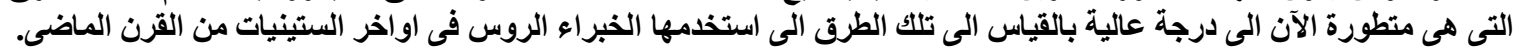

والله الموفق .......... 